\title{
CLINICAL RESULT OF PATIENTS WITH DISTAL BICEPS TENDON RUPTURE WITH ENDOBUTTON
}

\section{RESULTADO CLÍ́NICO DE PACIENTES COM RUPTURA DO TENDÃO DISTAL DO BICEPS COM ENDOBUTTON}

\author{
Jonatas Brito de Alencar Neto ${ }^{1}$ (1), Diego Frade Bernardes ${ }^{1}$ (D), Clodoaldo José Duarte de Souza ${ }^{1}$ (D), \\ marcos antônio Silva Girão ${ }^{1}$ (1), Pedro Henrique Messias da Rocha ${ }^{2}$ (i), Fernando antônio Mendes Façanha Filho ${ }^{1}$ (D)
}

1. Instituto Doutor José Frota, Department of Orthopedics and Traumatology, Fortaleza, CE, Brazil.

2. Universidade Federal do Ceará, Fortaleza, CE, Brazil.

\section{ABSTRACT}

Objective: To evaluate the results obtained in the repair of distal biceps injury using the single-incision approach with endobutton use; complications; and ability to return to sport. Methods: 14 athletes with rupture of the distal tendon of the biceps brachii submitted to surgical repair using a single route with endobutton were evaluated. The parameters analyzed were: Mayo Elbow Performance Score (MEPS), flexion-extension range of motion and pronation-supination, and the ability to return to sports practice. Results: Most injuries were related to weightlifting (57.1\%), vaquejada (35.7\%) and judo (7.2\%). All operated patients returned to sports activities, maintaining the elbow range of motion. Two cases faced complications due to neuropraxia (one case affecting the posterior interosseous nerve and the other the radial sensitive nerve). However, there was spontaneous resolution in 10 weeks of follow-up. One case - due to the late presentation and presence of fibrotic adhesions - evolved with a deficit of the lateral cutaneous nerve of the forearm and later with osteolysis and heterotopic ossification. Conclusion: Repair of the distal tendon of the biceps by the one-way technique is a safe method, with a low complication rate and a short rehabilitation period. Level of Evidence III, Retrospective comparative study.

Keywords: Athletes. Elbow. Sports. Rupture.

\section{RESUMO}

Objetivo: Avaliar os resultados obtidos nos reparos da lesão de bíceps distal pela técnica de via única com uso de endobutton; bem como avaliar as complicações e a capacidade de retorno ao esporte. Métodos: Avaliou-se catorze atletas com ruptura do tendão distal do bíceps braquial submetidos à técnica de reparo cirúrgico por via única com uso de endobutton. Os parâmetros analisados foram: escore MEPS (Mayo Elbow Performance Score), arco de movimento de flexão-extensão e pronação-supinação. Além da capacidade de retorno ao esporte. Resultados: A maioria das lesões foi relacionada à musculação (57,1\%); em seguida vaquejada (35,7\%) e judô (7,2\%). Todos os pacientes operados retornaram às atividades esportivas, mantendo o arco de movimento do cotovelo. Em dois casos houve complicações devido à neuropraxia (um caso acometendo o nervo interósseo posterior e outro o nervo sensitivo radial). Entretanto, houve resolução espontânea em dez semanas de acompanhamento. Um caso, por conta da apresentação tardia e presença de aderências fibróticas, evoluiu com déficit do nervo cutâneo lateral do antebraço e posteriormente com osteólise e ossificação heterotópica, tendo que ser reabordado cirurgicamente. Conclusão: Reparo do tendão distal do bíceps pela técnica de via única é um método seguro, com baixa taxa de complicação e curto período de reabilitação. Nível de Evidência III, Estudo retrospectivo comparativo.

Descritores: Atletas. Cotovelo. Esportes. Ruptura.

Citation: Alencar Neto JB, Bernardes DF, Souza CJD, Girão MAS, Rocha PHM, Façanha Filho FAM. Clinical result of patients with distal biceps tendon rupture with endobutton. Acta Ortop Bras. [online]. 2021;29(3):149-152. Available from URL: http://www.scielo.br/aob.

\section{INTRODUCTION}

Distal biceps tendon injuries are uncommon, corresponding to only $3 \%$ of biceps injuries, whereas the involvement of the proximal portion of long head occurs in approximately $96 \%$ of the cases. ${ }^{1}$ Tendon injuries in athletes are often related to the erroneous application of technical movements, uninterrupted training and high training loads, causing the inflammation and weakening of these structures. ${ }^{2}$
Rupture of the distal biceps tendon occurs during weightlifting, with the elbow flexed at $90^{\circ}$ or in the unexpected eccentric contraction phase; the primary observed symptoms in these cases are pain, edema, ecchymosis, and deformity, with a palpable defect in the antecubital region. ${ }^{3}$ Two independent risk factors were identified and related to the increase in distal biceps injury: smoking and use of steroids, both factors are believed to weaken the tendon, especially at the tendon-bone interface. ${ }^{4,5}$

All authors declare no potential conflict of interest related to this article. 
Treatment depends on the patient's demand, age, and the aesthetic repercussions that the injury may represent to the individual, which can be repaired surgically or not. The option for non-surgical treatment can lead to a decrease in the supination strength of the forearm of up to $40 \%$, which, with sustained contraction in this position, can reach up to $79 \%$ loss of resistance. ${ }^{6}$ This functional limitation may cause some degree of fatigue or restriction to certain repetitive activities, thus reinforcing the importance of repairing these injuries, especially in athletes due to their high functional demand. Several repair techniques be used for the surgical treatment of these injuries, such as the fixation of anchors, interference screws, transosseous points, and using the endobutton. Depending on the surgeon's experience and the fixation method used, the approach can be a single anterior or double incision, both described in the literature as ensuring satisfactory results. ${ }^{7-9}$

The endobutton technique is one of the most biomechanically stable fixation methods available, with low complication rates and good functional results. ${ }^{10}$

This study demonstrates the clinical outcomes of the treatment of distal biceps brachii tendon injury in athletes treated surgically with the endobutton using the single-incision anterior approach, according to the technique described by Bain et al. ${ }^{7}$

\section{MATERIALS AND METHODS}

This was a retrospective study of a case series conducted with the analysis of medical records of athletes with distal biceps brachii tendon injuries caused by sports activities undergoing single-incision technical repair using the endobutton.

Patients with a clinical history compatible with distal biceps brachii tendon injury, positive hook test, or inverted Popeye sign, that underwent surgery using the single-incision anterior approach with endobutton use, and that were followed postoperatively for 24 weeks were included in the study. The exclusion criteria were: cases of injury unrelated to sports activities, patients who underwent surgery using a technique other than the single-incision anterior approach with endobutton, cases that did not complete the minimum postoperative follow-up period established in this study (24 weeks), and patients who did not accept to participate in the survey.

This study analyzed the medical records of 24 male patients, ranging from November 2013 to April 2017, with complete rupture of the distal biceps brachii tendon, who were operated by two surgeons with experience in Shoulder and Elbow Surgery at a tertiary hospital specialized in trauma.

The following clinical parameters were evaluated in this study: patient identification by numerical designation, age, activity that caused the trauma, functional results of the dynamic range of motion (DROM) of flexion-extension and active and passive pronosupination, clinical complications (vascular or neurological injury), radiographic complications (loss of fixation), and the Mayo Elbow Performance Score (MEPS) ${ }^{11}$ (Table 1).

The rehabilitation protocol employed included physical therapy in the immediate postoperative period with free passive flexion, passive extension limited to $30^{\circ}$, and free pronosupination until the third week. Between three and six weeks, free extension was added to the previous exercises, while free pronosupination was maintained. After six weeks, active flexion-extension with progressive loads was authorized.

This study was previously authorized by the Research Ethics Committee of the hospital where the study was carried out, under Protocol Number 74419417.2.0000.5047.

\section{Surgical technique}

Under anesthetic sedation and regional brachial plexus block, the patient was placed in horizontal supine position with the affected elbow on an armrest.

Access was carried out through a single 2-centimeter $(\mathrm{cm})$ transverse incision, slightly distal to the region of the cubital fold, according to Henry's approach for the proximal third of the forearm, followed by subcutaneous dissection, identification, and protection of the lateral cutaneous nerve. Next, the distal tendon of the ruptured biceps brachii was identified and repaired using Krakow stitches $1.0 \mathrm{~cm}$ distally from the tendon, and another $3.0 \mathrm{~cm}$ with Bunnel stitches, using non-absorbable co-braided polyethylene threads (Force Fiber ${ }^{\circledR}$, San Jose, California, USA), with later regularization and cruentation of the proximal stump and fixation to the endobutton $\left(\right.$ Implanet ${ }^{\circledR}$, Bordeaux, France) - Figure 1A. Similar to Henry's approach, deep dissection was performed, identifying the radial bicipital tubercle. With the forearm in total supination, we perpendicularly drilled at the most anatomical point of the tendon around the radius tuberosity in its anterior cortex (cis) with a 7.0 millimeter $(\mathrm{mm})$-thick drill to fit the tendon. A new perforation with a $4.5 \mathrm{~mm}$ drill was conducted in order to perforate the posterior cortex (trans) for the passage of the endobutton. Two threads were inserted through the holes at the endobutton ends. With the aid of a threaded Steinmann pin, the two wires were passed through the orifice of the bicipital tubercle, extending beyond the skin on the posterior facet of the forearm (Figure 1B).

The elbow was flexed at approximately $90^{\circ}$ when one of the wires was pulled, allowing the endobutton to pass through the bone perforation. When the endobutton passed the trans cortex, the other wire was pulled to secure it. At this moment, a radiological control was carried out to check the positioning of the material. After checking, surgical plane occlusal, bandaging, and temporary immobilization of the flexed elbow were conducted for initial postoperative comfort (Figures 1C and 1D).

Table 1. Functional results of the operated patients.

\begin{tabular}{|c|c|c|c|c|c|}
\hline \multirow{2}{*}{ PATIENT } & \multirow{2}{*}{ AGE (years) } & \multirow{2}{*}{ TRAUMA ACTIVITY } & \multicolumn{2}{|c|}{ FUNCTIONAL RESULTS AT 24 WEEKS } & \multirow{2}{*}{ MEPS } \\
\hline & & & FLEXION-EXTENSION & PRONOSUPINATION & \\
\hline$\# 1$ & 31 & Vaquejada & $140 / 0$ & $80 / 80^{\circ}$ & 100 \\
\hline$\# 2$ & 21 & Weightlifting & $140 / 0^{\circ}$ & $80 / 80^{\circ}$ & 100 \\
\hline$\# 4$ & 31 & Weightlifting & $140 / 0^{\circ}$ & $80 / 70^{\circ}$ & 100 \\
\hline \# 5 & 61 & Weightlifting & $140 / 0^{\circ}$ & $80 / 80^{\circ}$ & 100 \\
\hline$\# 8$ & 38 & Vaquejada & $140 / 0^{\circ}$ & $80 / 80^{\circ}$ & 100 \\
\hline$\# 9$ & 61 & Weightlifting & $140 / 0^{\circ}$ & $60 / 60^{\circ}$ & 100 \\
\hline$\# 10$ & 34 & Vaquejada & $140 / 0^{\circ}$ & $80 / 80^{\circ}$ & 100 \\
\hline$\# 11$ & 29 & Weightlifting & $140 / 0^{\circ}$ & $75^{\circ} / 85^{\circ}$ & 100 \\
\hline$\# 12$ & 49 & Vaquejada & $140 / 0^{\circ}$ & $75 / 85^{\circ}$ & 100 \\
\hline
\end{tabular}



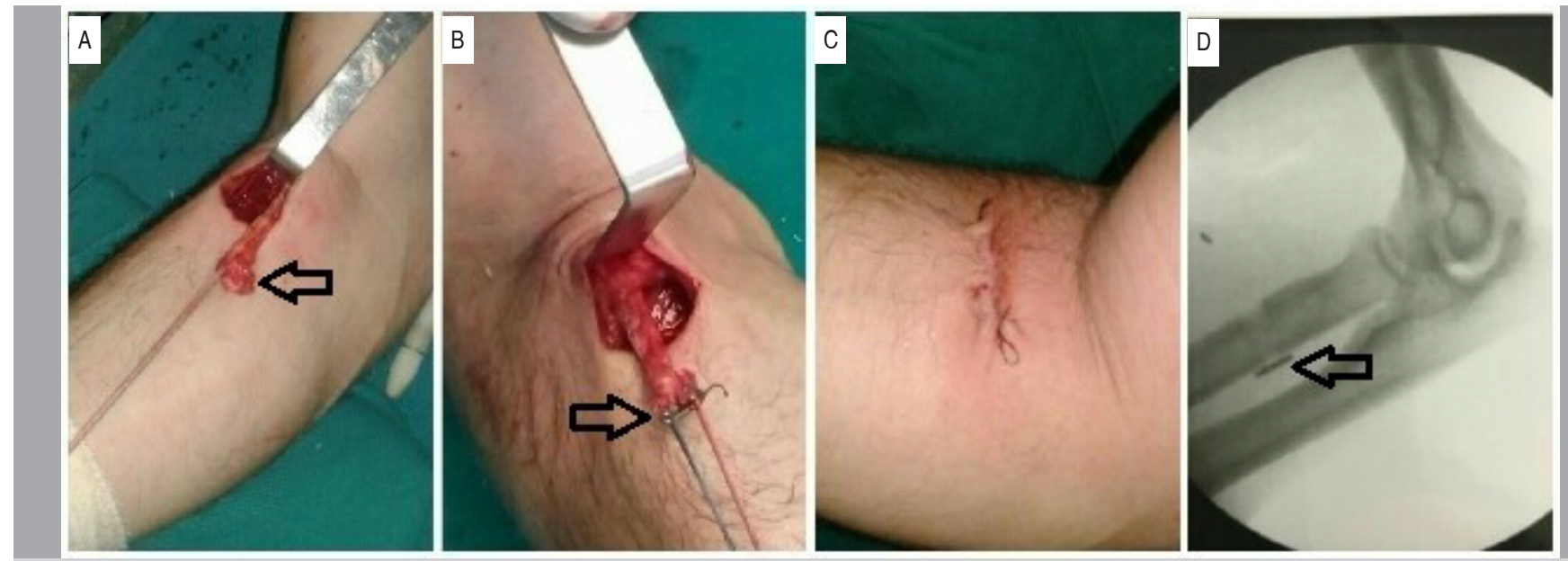

Figure 1. Intraoperative sequencing of reconstruction of the distal tendon of biceps branchii with the one-way technique using endobutton. Repair of the ruptured distal biceps tendon. A: anterior incision and preparation of the tendon; B: fixation of the endobutton; C: visual aspect at the end of the surgery; D: demonstration of the endobutton positioning.

\section{RESULTS}

The medical records of 24 patients were evaluated in this study. Ten patients were excluded from the sample because they did not meet the inclusion criteria, resulting in 14 elbows of the individuals who took part in the survey. The epidemiological profile of the participants in this assessment consisted of male patients (100\%), with 35.6 years as the mean age (range 21-61 years), who sustained rupture of the distal biceps brachii tendon of the dominant limb in $100 \%$ of the cases. In the analysis, we observed that most participants (57.1\%) sustained injury during weightlifting, 35.7\% during the practice of vaquejadas (a typical sport in the Northeastern Brazil), and only one case (patient identified as number 3) was injured while practicing judo.

Regarding the follow-up of the monitored patients, the absence of pain was reported between 3 and 10 weeks, and full-load activities were authorized on average at 24 weeks. The 14 patients that underwent surgery achieved a functional range of motion, returning to their sports activities at the end of treatment, and the MEPS score was excellent in all cases. A complication rate of $21.4 \%$ (3 cases out of 14) was observed, two of which were neurological injuries (patient 11 exhibited an injury to the posterior interosseous nerve and patient 14 , an injury to the lateral antebrachial cutaneous nerve with osteolysis of the endobutton passage tunnel and formation of heterotopic ossification in the tendon repair zone - Figure 2) and one (patient 4) that evolved with biceps muscle rupture.
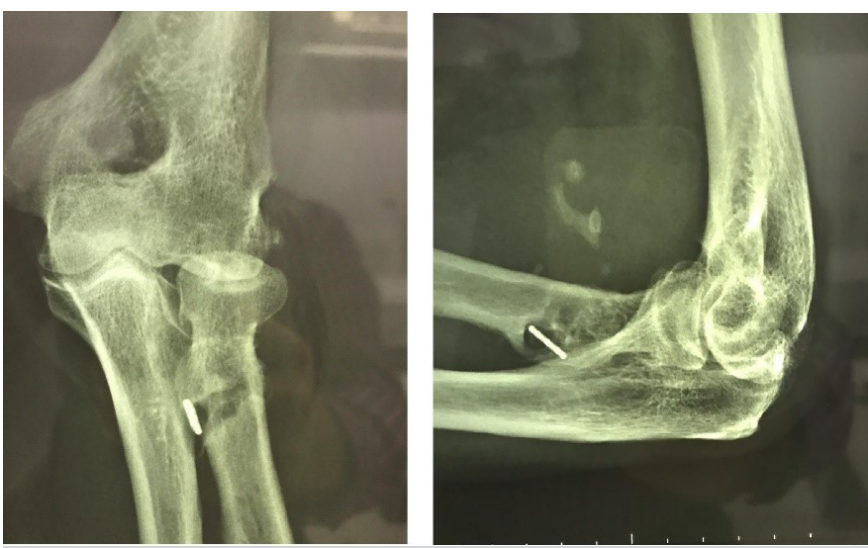

Figure 2. Osteolysis of the endobutton tunnel, with formation of heterotopic ossification in the tendon repair zone.

\section{DISCUSSION}

Distal biceps tendon ruptures are uncommon and have an incidence rate of 1.2 cases per 100,000 people per year. These injuries mostly affect men aged $30-50$ years. ${ }^{5}$ In this study, corroborating these data, the mean age of the analyzed patients, all of which were male, was 36.3 years (range 21-61 years). Ford et al. ${ }^{12}$ evaluated 970 cases of distal biceps tendon repair and obtained an average age of 49 years. Similarly, the most patients analyzed were male (97.6\%).

Regarding dominance, in $100 \%$ of the cases, the rupture of the distal biceps tendon occurred in the dominant limb. Such finding corroborates data in the literature that show the involvement of the dominant limb in most cases (81.8\%). ${ }^{8}$ Perhaps, the fact that we evaluated only athletes in this study - whose injuries occurred during sports activities - explains why the injury affected the dominant limb in all cases.

Considering the return to sports, all patients went back to their activities at the same level as before the injury within the follow-up period, an average of 24 weeks. Maciel et al., 8 reported a similar result regarding the return to activities after three months, a shorter period than in our study, using a single-incision anterior approach and anchor fixation, with a complication rate of $27.2 \%$. The complication rate observed herein was $21.4 \%$, corroborating data from the literature that show a similar percentage (26.4\%). ${ }^{13}$

According to Bain et al., ${ }^{7}$ pronosupination is the leading movement that can change after the surgical treatment of these injuries. The patients reached an average of $80 / 81^{\circ}$ with endobutton use, using the single-incision anterior approach. In our case series, $80 \%$ of the patients obtained normal DROMs, similar to the preoperative state. The remaining $20 \%$, despite not achieving normal DROMs $\left(>80 / 80^{\circ}\right)$, obtained functional results with more than $100^{\circ}$ of DROM. Garcia et al. ${ }^{14}$ reported an average loss of pronation of $14.4^{\circ}$ when using the double-incision technique with transosseous suture, it was necessary to reoperate a patient for presenting a loss above $90^{\circ}$, thus rendering the DROM non-functional. Meanwhile, Prabhu et al., ${ }^{13}$ obtained a result similar to that found in our study, with pronation and supination of $75^{\circ}$ and $80^{\circ}$, respectively, in patients operated using the single-incision anterior approach and associated fixation of the bicortical endobutton with an interference screw. Surgical reoperation was required in one patient due to the need for procedure review ( $7 \%$ of the operated cases), more than a year after the initial surgery.

In the study by Matzon et al., ${ }^{15}$ the authors found that $2.4 \%$ of the operated cases presented complications that required new surgery 
due to tendon rupture or deep infection. Meanwhile, Samuel E. Ford et al. ${ }^{12}$ observed a reoperation rate of $4.5 \%$. Notably, both studies evaluated a much larger number of cases (212 and 970 cases, respectively), providing more statistical significance to these indexes. Specifically, considering the complications found in this study, patient number 11 sustained an injury to the posterior interosseous nerve; he exhibited significant muscle mass, leading us to believe that the injury was caused by excessive traction to promote adequate surgical exposure. Burchette et al. ${ }^{16}$ reported that maintaining sufficient and safe exposure during the repair of the distal biceps using the single-incision technique is challenging, especially in muscular individuals, as was the case of this patient. The consequent loss of the visual field can compromise the safety and efficiency of the technique, which may result in such complications. Maciel et al. ${ }^{8}$ also showed a case with posterior interosseous nerve injury, which, as in our patient, recovered spontaneously after approximately 10 weeks of follow-up.

Regarding the case of patient number 14, who practices weightlifting, since he presented his injury 34 days later, it led to technical difficulties in the procedure due, primarily, to fibrotic adhesions. The patient evolved with a deficit of the lateral cutaneous nerve of the forearm, osteolysis of the endobutton tunnel, and formation of heterotopic ossification in the tendon repair zone. Initially, he had no symptoms of pain and returned to sports normally within four months after surgery. After approximately one year, the patient began to experience pain in movements with intense load, requiring a new surgical approach (Figure 2).
Patient number 4, during an inadvertent eccentric contraction movement on the third postoperative day, underwent muscle fraying above the tendon suture zone, in the region of the tendon muscle, without compromising tendon fixation to the bone, later confirmed by ultrasound; this event was related to the patient's non-adherence to postoperative care through immobilization (sling). In this case, management was conservative with medication, guidance, monitoring, and adequate immobilization. There was no functional impairment, but esthetic deformity occurred.

The limitations encountered in this study include the limited number of analyzed cases (14 patients), the absence of a comparative group to better validate the reported data, and the limited postoperative follow-up period ( 24 weeks), as well as the lack of dynamometric strength tests for evaluation and comparison between the pre and postoperative levels of the patients in this study. The patient follow-ups will be maintained, and new surveys will be conducted with strength tests, as well as evaluations and comparisons with results obtained from other surgical techniques.

\section{CONCLUSION}

The repair of acute distal biceps injury in athletes using the single-incision anterior approach with endobutton fixation proved to be an adequate therapeutic option, with an index of complications within that reported in the researched literature for other techniques and rendered excellent clinical results.

AUTHORS' CONTRIBUTIONS: Each author contributed individually and significantly to the development of this article. JBAN: review of the article, intellectual concept of the article and final approval of the manuscript; DFB: writing and review of the article; CJDS: data analysis and surgery; MASG: writing and data analysis; PHMR: writing and review of the article; FAMFF: interpretation of statistical data and final approval of the manuscript.

\section{REFERENCES}

1. Terra BB, Rodrigues LM, Lima ALM, Cabral BC, Cavette JM, Nadai A, et al. Reparo direto das lesões distais crônicas do tendão bicipital. Rev Bras Ortop. 2016;51(3):303-12.

2. Suzarte MC. Lesões musculares, tendinosas e ligamentares relacionadas às atividades esportivas [dissertation]. Feira de Santana: Faculdade Nobre de Feira de Santana; 2010. 13 p. Accessed on: 2017 Sept 11. Available from: http://www.ebah.com.br/content/ABAAABfyYAK/lesoes

3. Canale ST, Beaty JH. Campbell Cirurgia Ortopédica. 12th ed. Rio de Janeiro: Elsevier; 2017

4. D'Alessandro DF, Shields CL Jr, Tibone JE, Chandler RW. Repair of distal biceps tendon ruptures in athletes. Am J Sports Med. 1993;21(1):114-9.

5. Safran MR, Graham SM. Distal biceps tendon ruptures: incidence, demographics, and the effect of smoking. Clin Orthop Relat Res. 2002;404:275-83.

6. Baker BE, Bierwagen D. Rupture of the distal tendon of the biceps brachii. Operative versus non-operative treatment. J Bone Joint Surg Am. 1985;67(3):414-7.

7. Bain GI, Prem H, Heptinstall RJ, Verhellen R, Paix D. Repair of distal biceps tendon rupture: a new technique using the Endobutton. J Shoulder Elbow Surg. 2000;9(2):120-6.

8. Maciel RA, Costa PS, Figueiredo EA, Belangero PS, Pochini AC, Ejnisma B. Lesão do bíceps distal aguda: reparo por via única e fixação por âncora de sutura. Rev Bras Ortop. 2017;52(2):148-53.
9. Miyazaki AN, Fregoneze M, Santos PD, Silva LA, Sella GV, Duarte DC, et al. Avaliação funcional dos pacientes com lesão da inserção distal do músculo bíceps braquial tratados cirurgicamente. Rev Bras Ortop. 2014;49(2):129-33.

10. Mazzocca AD, Burton KJ, Romeo AA, Santangelo S, Adams DA, Arciero RA Biomechanical evaluation of 4 techniques of distal biceps brachii tendon repair. Am J Sports Med. 2007;35(2):252-8.

11. Morrey BF, An KN, Chao EYS. Functional evaluation of the elbow. In: Morrey BF, editor. The Elbow and Its Disorders. 2nd ed. Philadelphia: WB Saunders; 1993. p. 86-89.

12. Ford SE, Andersen JS, Macknet DM, Connor PM, Loeffler BJ, Gaston RG. Major complications after distal biceps tendon repairs: retrospective cohort analysis of 970 cases. J Shoulder Elbow Surg. 2018;27(10):1898-906.

13. Prabhu J, Faqi MK, Al-Khalifa F, Awad RK. Modified Tension - Slide Technique for Anatomical Distal Biceps Tenodesis using a Bicortical Endobutton and a Tenodesis Screw. J Orthop Case Rep. 2016;6(5):104-8.

14. Garcia JC Jr, Castro Filho CDC, Mello TFC, Vasconcelos RA, Zabeu JLA, Garcia JPM. Lesão do bíceps distal: avaliação funcional e dinamometria digital da sua reconstrução pela técnica da minidupla via de mayo. Rev Bras Ortop. 2012;47(5):581-7.

15. Matzon JL, Graham JG, Penna S, Ciccotti MG, Abboud JA, Lutsky KF, et al. A Prospective Evaluation of Early Postoperative Complications After Distal Biceps Tendon Repairs. J Hand Surg Arm. 2018;44(5):382-6.

16. Burchette D, Avasthi A, Phadnis J. Single-incision distal biceps tendon repair using spinal retractors to achieve optimum exposure. Ann R Coll Surg Engl. 2018;100(1):78. 